Article Type: Research Paper

\title{
Testing the Existence of Natural Resource Curse in Indonesia: The Role of Financial Development
}

\author{
Sedwivia Ridena ${ }^{1 *}$, Nurarifin ${ }^{1}$, Wawan Hermawan ${ }^{2}$, and \\ Ahmad Komarulzaman ${ }^{2}$
}

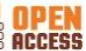

\author{
AFFILIATION: \\ ${ }^{1}$ Statistics Indonesia, West \\ Sumatra, Indonesia \\ 2Department of Economics, Faculty \\ of Economics and Business, \\ Universitas Padjajaran, West Java, \\ Indonesia
}

\section{*CORRESPONDENCE:}

sayridena@gmail.com

THIS ARTICLE IS AVALILABLE IN:

http://journal.umy.ac.id/index.php/esp

DOI: 10.18196/jesp.v22i2.10977

\section{CITATION:}

Ridena, S., Nurarifin, N., Hermawan, W., \& Komarulzaman, A. (2021). Testing the Existence of Natural Resource Curse in Indonesia: The Role of Financial Development. Jurnal Ekonomi \& Studi Pembangunan, 22(2), 213227.

\section{ARTICLE HISTORY}

Received:

27 Jan 2021

Revised:

29 Mar 2021

19 May 2021

08 Jun 2021

Accepted:

11 Sep 2021

\begin{abstract}
Natural resources may become a blessing that can contribute to societies' welfare increases. Yet natural resource abundance could also become a curse for countries' economic development. Numerous studies have investigated the relationship between natural resources and economic performance. However, the results remain ambiguous and have no consensus in the literature. In specific, most literature focused only on testing the curse's existence, while studies that involve the role of financial development in mediating the nexus remain scarce. To the best of our knowledge, this is a pioneer study in a developing country endowed by natural resources. Using panel data of 33 provinces from 2012 to 2018, this study implements the Generalized Method of Moments (GMM) technique to examine the existence of the natural resource curse and scrutinize the role of financial development in mitigating the curse. Results show that Indonesia potentially experiences a natural resource curse. Nonetheless, the negative effect of natural resources on economic growth could be mitigated by enhancing the role of financial development to reach a certain threshold over economic output. This study recommends policymakers to not only increase financial development across the provinces but also pay more serious attention to other factors causing the natural resource curse in Indonesia.
\end{abstract}

Keywords: Natural Resource Curse; Financial Development; Economic Growth; Economic Development

JEL Classification: Q56; G21; 044; 013

\section{Introduction}

Conventional views tend to assume that countries endowed with natural resources experience a better economic performance since the natural resource is potentially a catalyst for economic activities (Ben-Salha et al., 2018). Natural resources are a blessing since they have contribution towards economic activities to help improving welfare (Andersen, 2006). Several studies have successfully found a positive impact of natural resources on economic growth (e.g. Cavalcanti et al., 2011; Hilmawan \& Clark, 2019; Michaels, 2010).

Nonetheless, these views faced a critical challenge. A significant number of researchers have claimed that natural resources could be a curse for a nation. 
It was Auty (1994) who firstly constructed a natural resource curse hypothesis, implying a negative relationship between natural resource abundance and economic performance. He postulates that resource-dependent nations attempting to develop advantaged industries possibly face problems in improving their economic performance. Instead of fostering economic growth, their economic growth rate remains low and their ecological environment is gradually damaged. Sachs and Warner (1995) examined the nexus between those variables and found that resource-abundant countries tend to have a low rate of economic growth than resource-scarce countries. Gelb (1988) found that government revenues from natural resource tend to exacerbate economic condition when the interest rate increases. This is because countries that are highly dependent on oil export tend to hamper other sectors to develop, for example, trade sectors. Trade sectors may suffer when the interest rate increases as it bears a significant production cost. For example, Gylfason and Zoega (2006) researched 85 natural resource-rich countries and found a negative relationship between resource abundance and economic growth through saving transmission and investment. Atkinson and Hamilton (2003) also tested the linkage between natural resource rent and saving in 103 countries and found that countries blessed by rich natural resources had a low rate of saving. Marques and Pires (2019) also examined the existence of the natural resource curse in gas-rich countries during 1993-2015 and concluded that gas dependence may hamper economic growth in the long run.

Natural resource endowment could be either a blessing or a curse for countries' development. Economists who believe that natural resources can be a blessing argued that natural resources play a crucial role in the process of economic development. Specifically, Rostow stated that natural resource abundance would allow developing nations to make a critical transformation from under-development to industrial take-off (Badeeb et al., 2017). Therefore, the economists believed that natural resources could promote industrial development, shape markets, and encourage investment. On the other hand, natural resources could also be a curse for nations. Badeeb et al. (2017) classified the mechanisms into economic and political factors. The economic explanations refer to the Dutch disease phenomenon, commodity price volatility, economic mismanagement, and education neglect, whereas the political explanations relate to rentseeking practices, weak institutions, and corruption.

Natural resource studies have also been conducted in Indonesia, which resulted in varied findings. Rosser (2007) conducted empirical research testing the linkage between the oil and gas sector and economic growth in Indonesia between 1970 and 1980. He found that Indonesia can anticipate a natural resource curse. Hilmawan and Clark (2019) examined the linkage using municipality and regency data in Indonesia and found that mining dependence had a positive effect on real per capita GRDP. Nevertheless, other streams of literature in Indonesia have found the existence of this curse. Using cross-sectional data at the municipality/regency level, Komarulzaman and Alisjahbana (2006) claimed that oil revenue had a negative association with economic growth. Moreover, Edwards (2016) found that mining dependence was more likely to reduce human capital investment. In addition, Rahma et al. (2021) stated that the curse indeed exists in Indonesia at a province 
level, which means that mining dependence is not a guarantee for a country to achieve sustainable development.

Literature reveals various findings regarding the relationship between natural resources and a country's economic development. Havranek et al. (2016) found that $40 \%$ of papers found a negative association, $20 \%$ of papers claimed the sign of the links is positive, and only $20 \%$ found no adequate evidence to conclude the linkage. The contradictory findings were possibly due to endogeneity ignorance in the analysis (Badeeb et al., 2017), and owing to weak robustness checks (Hilmawan \& Clark, 2019).

Most of the previous studies focused only on the testing of the existence of a resource curse without an option of mitigating it. Researchers have examined the relationship between natural resources and economic development, attempting to scrutinize whether or not the curse significantly exists. However, the study seeks to include financial development as a channel for mitigating the curse remains scarce. Erdoğan et al. (2020) argued that the development of a financial system was crucial for natural resources to have a positive impact on fostering economic growth. They stated that there was a certain threshold of the level of financial development, which determined the effect of natural resources on economic growth (Erdoğan et al., 2020).

Gylfason (2004) conducted an empirical study involving 85 countries from 1965 to 1998 and found that natural resource affected growth directly and indirectly through financial development transmission. Moradbeigi and Law (2017) found that interaction between financial development and natural resource abundance (proxied by oil rent) had a positive association with economic growth, which means could curb the natural resource curse. Rongwei and Xiaoying (2020) used panel data of 30 provinces in China from 2005 to 2018 to test the role of financial development on natural resource abundance and economic growth relationship and found that financial development could mitigate the curse in China.

In addition, financial development could curb the natural resource curse through an economic mechanism, for example, the volatility of natural resource commodity prices. Economists have argued that natural resource price fluctuations decrease economic growth. In an economic boom period, the resource prices surge sharply with increasing demand. Meanwhile in an economic downturn period, the resource prices decline dramatically followed by decreasing demand. The volatility of natural resource commodity prices has caused economic fluctuations in the country, causing pro-cyclical fluctuations in government income and export revenues. This volatility increases uncertainty and makes it difficult to calculate natural resource revenues, thus making planning government finance revenues and expenditures more challenging. In that condition, strengthening financial development can have a critical role in curbing the curse. According to Rongwei and Xiaoying (2020), the financial system is able to establish a fund for controlling natural resource revenue, maintaining a reasonable level of resource revenue, and retrieving resource revenue higher than the average level of the fund. Therefore, it can effectively avoid economic fluctuations caused by market instability of resource revenue. The argument is also consistent with Beck (2011) arguing 
that the financial system could mitigate the condition when natural resource revenues decrease due to price fluctuation; it could increase productivity and allocate natural resources optimally thus fostering growth. He also affirmed that natural resource revenue can be a tool for establishing a financial system to be more effective, which in turn improving the business circle (Beck, 2011). A high natural resource revenue can be utilized to foster other sectors through productive investment intermediated by financial institutions (Erdoğan et al., 2020).

Studies that involve financial development in natural resources and economic performance nexus conducted in Indonesia remain scarce. This study intends to fill that gap by examining the existence of the natural resource curse and scrutinizing the role of financial development. The analysis takes two important factors mentioned in previous literature into consideration, namely endogeneity, and robustness check issues.

In specific, this study is motivated by the two most relevant analyses conducted by Hilmawan and Clark (2019), and Rongwei and Xiaoying (2020). The first considers with weak robustness checks by implementing three different empirical techniques but not taking into account the role of financial development on their analysis, whereas the latter considers endogeneity issues by implementing a more flexible econometric model but not bearing in mind the robustness checks by employing different indicators for natural resources and financial development, for example. This study employs the two most used natural resources and financial development indicators, and it attempts to further analyses the variables that potentially lead to the natural resource curse by dividing a natural resource indicator, namely natural resource revenue, into mining revenue, and oil and gas revenue.

This study has two objectives: (1) revealing the possibility of the existence of the natural resource curse in Indonesia so that policymakers can take steps to mitigate it well and (2) proposing a mechanism to reduce the curse potency by strengthening financial development in the country.

The results of the study are twofold. First, there is a potential existence of natural resources in Indonesia. In every one percentage point increase of natural dependence, economic growth is expected to decline by 0.28 to 0.34 percentage points. Specifically, in contrast to the mining revenue that only revealed limited evidence of the existence of the curse, the revenue from oil and gas provides stronger evidence that supports the natural resource curse in Indonesia. Second, financial development potentially becomes a channel for mitigating the curse in the country with the threshold of at least 28 to 34 per cent. These findings provide empirical evidence to help the government formulating natural resource-related policies to avoid the curse through an alternative mechanism by enhancing financial development. The government needs to pay attention to financial sectors as a channel for mitigating and reducing the curse. Additionally, they should guarantee to reduce rent-seeking practices among elites and to strengthen institution quality. 


\section{Research Method}

Data used in this study were collected from 33 provinces on annual basis from 2012 to 2018. We exclude North Kalimantan, a new province in Indonesia because of data scarcity issue. The variables used in this research are adapted from Rongwei and Xiaoying (2020). The dependent variable is per capita economic growth measured by the difference value of the natural logarithm of real Gross Regional Domestic Product (GRDP) at periods $t$ and t-1. BPS-Statistics Indonesia provides GRDP data with 2010 as a base year.

Table 1 Data and definition used in the analysis

\begin{tabular}{|c|c|c|c|c|c|}
\hline No & Variable & Definition & Abbrev. & $\begin{array}{l}\text { Unit of } \\
\text { Measurement }\end{array}$ & Source \\
\hline 1 & $\begin{array}{l}\text { Per capita } \\
\text { economic growth }\end{array}$ & $\begin{array}{l}\text { The logarithmic difference } \\
\text { in per capita GRDP }\end{array}$ & $y$ & Natural log & $\begin{array}{l}\text { BPS-Statistics } \\
\text { Indonesia }\end{array}$ \\
\hline \multicolumn{6}{|c|}{ Natural Resource Indicators } \\
\hline 2 & $\begin{array}{l}\text { Mining } \\
\text { Dependence }\end{array}$ & $\begin{array}{l}\text { Percentage of total mining } \\
\text { output over real GRDP }\end{array}$ & MINDEP & Per cent & $\begin{array}{l}\text { BPS-Statistics } \\
\text { Indonesia }\end{array}$ \\
\hline 3 & $\begin{array}{l}\text { Natural Resource } \\
\text { Revenue }\end{array}$ & $\begin{array}{l}\text { The percentage of total } \\
\text { natural resource revenue } \\
\text { (total of mining, oil, and gas } \\
\text { revenue) over total } \\
\text { government revenue }\end{array}$ & NRREV & Per cent & DJPK \\
\hline 4 & Mining Revenue & $\begin{array}{l}\text { The percentage of mining } \\
\text { revenue (DBH mining) over } \\
\text { total government revenue }\end{array}$ & MINREV & Per cent & DJPK \\
\hline 5 & Oil+gas Revenue & $\begin{array}{l}\text { The percentage of oil and } \\
\text { gas revenue (DBH oil and } \\
\text { gas) over total revenue }\end{array}$ & OILGASREV & Per cent & DJPK \\
\hline \multicolumn{6}{|c|}{ Financial Development } \\
\hline 6 & Credit & $\begin{array}{l}\text { The percentage of credit to } \\
\text { the private sector over total } \\
\text { nominal GRDP }\end{array}$ & Credit & Per cent & OJK \\
\hline 7 & $\begin{array}{l}\text { Deposit Money } \\
\text { Bank }\end{array}$ & $\begin{array}{l}\text { The percentage of deposit } \\
\text { money bank over total } \\
\text { nominal GRDP }\end{array}$ & DPK & Per cent & OJK \\
\hline \multicolumn{6}{|c|}{ Control Variables } \\
\hline 8 & $\begin{array}{l}\text { Human Capital } \\
\text { Investment }\end{array}$ & $\begin{array}{l}\text { The percentage of college } \\
\text { students over the total } \\
\text { population }\end{array}$ & $\mathrm{HCl}$ & Per cent & $\begin{array}{l}\text { BPS-Statistics } \\
\text { Indonesia }\end{array}$ \\
\hline 9 & $\begin{array}{l}\text { Economic } \\
\text { Fluctuations }\end{array}$ & $\begin{array}{l}\text { The absolute value of the } \\
\text { five-year moving standard } \\
\text { deviation of per capita } \\
\text { GRDP }\end{array}$ & $\mathrm{EF}$ & Billion Rupiah & $\begin{array}{l}\text { BPS-Statistics } \\
\text { Indonesia }\end{array}$ \\
\hline 10 & $\begin{array}{l}\text { Regional } \\
\text { Openness }\end{array}$ & $\begin{array}{l}\text { Total regional Foreign } \\
\text { Direct Investment (FDI) over } \\
\text { regional nominal GRDP }\end{array}$ & Open & Per cent & BKPM \\
\hline 11 & $\begin{array}{l}\text { Investment } \\
\text { Efficiency }\end{array}$ & $\begin{array}{l}\text { The share of total } \\
\text { investment over nominal } \\
\text { GRDP }\end{array}$ & $\mathrm{EI}$ & Per cent & BKPM \\
\hline
\end{tabular}


The study includes only non-renewable natural resources such as mining (coal and other mining), oil, and gas. Following previous works, this study utilizes the share of the mining sector over total GRDP (mining dependent) and the share (DBH, Dana Bagi Hasil) of natural resource revenue over the total of government revenue as proxies of natural resource indicators. DBH consists of the mining sector, oil, and gas revenues. The analysis then divided it into two components, mining revenue, and oil and gas revenue. Meanwhile, the financial development indicator in this study was proxied by private credit and deposit money banks as a share of nominal GRDP. These data were gathered from the Financial Services Authority.

This study employs control variables adopted by Rongwei and Xiaoying (2020), namely: human capital investment, economic fluctuations, regional openness, and investment efficiency. Human capital investment was proxied by the percentage of the total number of college students over total population; economic fluctuation is the absolute value of the five-year moving standard deviation of per capita GRDP; regional openness is measured by total regional Foreign Direct Investment (FDI) over regional nominal GRDP; and investment efficiency is the share of total investment over nominal GRDP. Table 1 summarizes the data used in the analysis.

Therefore, per capita output growth is defined as the logarithmic difference in per capita GRDP, which is determined by the initial level of per capita income $\left(y_{i, t-1}\right)$ as suggested by Barro (1996) and other explanatory variables following Rongwei and Xiaoying (2020) as have mentioned. Our model is then

$$
\begin{aligned}
& y_{i t}-y_{i(t-1)}=\Upsilon y_{i, t-1}+\beta_{1} N R_{i, t}+F D_{i, t}^{\prime} \beta_{2}+\beta_{3}\left(N R_{i, t} \cdot F D^{\prime}{ }_{i, t}\right)+x_{i t}^{\prime} \delta+\varepsilon_{i t} \\
& y_{i t}=(\Upsilon+1) y_{i(t-1)}+\beta_{1} N R_{i, t}+F D_{i, t}^{\prime} \beta_{2}+\beta_{3}\left(N R_{i, t} \cdot F D^{\prime}{ }_{i, t}\right)+x_{i t}^{\prime} \delta+\varepsilon_{i t} \\
& y_{i t}=\Upsilon^{*} y_{i(t-1)}+\beta_{1} N R_{i, t}+F D_{i, t}^{\prime} \beta_{2}+\beta_{3}\left(N R_{i, t} \cdot F D_{i, t}^{\prime}\right)+x_{i t}^{\prime} \delta+\varepsilon_{i t} \\
& \varepsilon_{i t}=\alpha_{i}+v_{i t} \\
& E\left(\alpha_{i}\right)=E\left(v_{i, t}\right)=E\left(\alpha_{i} v_{i, t}\right)=0
\end{aligned}
$$

Where $\Upsilon^{*}=\Upsilon+1, y_{i t}$, and $y_{i, t-1}$ are per capita GRDP of province $i$ at period $t$ and $t-1$, respectively. $N R_{i, t}$ represents the natural resource dependence of provinces at a certain period. $F D_{i, t}^{\prime}$ indicates vector of financial development indicators consisting of private credit and deposit money bank. $x_{i t}^{\prime}$ describes the vector of control variables. $\alpha_{i}$ and $v_{i t}$ are the individual-specific effect and the error term, respectively.

The study implements a dynamic generalised method of moments (dynamic GMM) estimation first developed by Arellano and Bond (1991). According to Das et al. (2016), the GMM approach has several advantages compared to OLS estimation. First, it allows estimating panel data with many individuals and a longer time length. Second, it permits us to control the individual-specific effect with the appropriate GMM variant. Third, GMM estimation can anticipate endogeneity problems in the model. 
To purge the individual-specific effect in equation (1), it needs to take the first difference so that it yields

$\Delta y_{i t}=\Upsilon^{*} \Delta y_{i, t-1}+\beta_{1} \Delta N R_{i, t}+\Delta F D_{i, t}^{\prime} \beta_{2}+\beta_{3} \Delta\left(N R_{i, t} \cdot F D^{\prime}{ }_{i, t}\right)+\Delta x_{i t}^{\prime} \delta+\Delta \varepsilon_{i t}$

With the following moment condition

$E\left(\omega_{i, s} \Delta \varepsilon_{i, t}\right)=0$ for $\mathrm{s}<\mathrm{t}$

Where $\omega_{i, s}$ is all independent variables that are treated as predetermined variables in equation (1). The estimation method using moment condition as in equation (5) is then called difference GMM (diff-GMM).

Several researchers then suggested utilizing additional moment conditions to yield better finite sample properties. Arellano and Bover (1995) and Blundell and Bond (1998) recommended using the following additional moment condition:

$E\left(\Delta \omega_{i, t} \varepsilon_{i, t}\right)=0$

The estimation method using additional moment conditions as in equation (6) is then called system GMM (sys-GMM). This study implements sys-GMM using a two-step standard error procedure to examine the existence of resource curse and testing the role of financial development in natural abundance and economic growth linkages. To avoid instrument proliferation, Roodman's (2009) recommendation was followed to limit the number of lags only using the first available lag of instrumenting variables of equation (1) and to collapse them.

\section{Result and Discussion}

Based on data, the average and the standard deviation of economic growth in Indonesia during the sample period was around 3.73 per cent and 2.22 per cent, respectively. Economic growth inequality among provinces in Indonesia remained high as its maximum and minimum values had a high range, accounted for -5.72 per cent and 18.40 per cent. Moreover, natural resource dependences, which were proxied by mining dependences GRDP and natural resource revenue, also showed high inequality in the country. Those variables had a high range between 0.17 per cent and 53.05 per cent for mining dependence GRDP, and between 0.00 per cent and 61.50 per cent for natural resource revenues. 
Ridena, Nurarifin, Hermawan, \& Komarulzaman

Testing the Existence of Natural Resource Curse in Indonesia: ...

Table 2 Summary statistics

\begin{tabular}{|c|c|c|c|c|c|c|c|}
\hline \multicolumn{2}{|c|}{ Variables } & $\begin{array}{l}\text { Unit of } \\
\text { Measurement }\end{array}$ & Obs. & Mean & $\begin{array}{l}\text { St. } \\
\text { Dev }\end{array}$ & Min & Max \\
\hline \multicolumn{2}{|c|}{ Per capita real GRDP (Y) } & $\begin{array}{l}\text { Million } \\
\text { Rupiahs }\end{array}$ & 231 & 37.19 & 29.12 & 10.03 & 165.87 \\
\hline \multicolumn{2}{|c|}{$\begin{array}{l}\text { Logarithmic differences of per } \\
\text { capita GRDP }\end{array}$} & Percentage & 231 & 3.73 & 2.22 & -5.72 & 18.40 \\
\hline $\begin{array}{l}\text { Natural } \\
\text { Resource }\end{array}$ & $\begin{array}{l}\text { Mining dependence } \\
\text { (Mindep) }\end{array}$ & Percentage & 231 & 11.63 & 12.22 & 0.17 & 53.05 \\
\hline \multirow[t]{3}{*}{ Dependence } & $\begin{array}{l}\text { Natural resource } \\
\text { revenue } \\
\text { (Nrrev) }\end{array}$ & Percentage & 231 & 5.81 & 10.88 & 0.00 & 61.50 \\
\hline & $\begin{array}{l}\text { Mining Revenue } \\
\text { (Miningrev) }\end{array}$ & Percentage & 231 & 2.15 & 4.76 & 0.00 & 27.04 \\
\hline & $\begin{array}{l}\text { Oil+gas Revenue } \\
\text { (Oilgasrev) }\end{array}$ & Percentage & 231 & 3.65 & 8.53 & 0.00 & 61.37 \\
\hline Financial & Credit & Percentage & 231 & 24.92 & 14.75 & 7.79 & 103.82 \\
\hline Development & $\begin{array}{l}\text { Deposit Money } \\
\text { Bank }\end{array}$ & Percentage & 231 & 25.92 & 18.06 & 9.25 & 120.34 \\
\hline \multicolumn{2}{|c|}{$\begin{array}{l}\text { Investasi Human Capital (hci, } \\
\text { human capital investment) }\end{array}$} & Percentage & 231 & 3.62 & 1.77 & 0.95 & 9.19 \\
\hline \multicolumn{2}{|c|}{ Economic Fluctuation (ef) } & $\begin{array}{l}\text { Million } \\
\text { Rupiahs }\end{array}$ & 231 & 5.78 & 4.86 & 0.59 & 28.93 \\
\hline \multicolumn{2}{|c|}{ Regional Openness (open) } & Percentage & 23 & 3.65 & 3.89 & 0.01 & 20.04 \\
\hline \multicolumn{2}{|c|}{ Investment efficiency (ie) } & Percentage & 231 & 5.37 & 4.26 & 0.17 & 20.55 \\
\hline
\end{tabular}

\section{The Existence of the Natural Resource Curse in Indonesia}

Table 3 presents the regression results of economic growth on several natural resources and financial development indicators. Overall, it revealed the potential existence of natural resources in Indonesia even though the effect was unclear when using mining dependence GRDP (Model 1 and Model 2). Model 3 and Model 4, which pair natural resource revenue (nrrev) with credit and deposit variables, showed a negative relationship between natural resources and economic growth. In every one percentage point of nrrev increase, economic growth would decline by 0.28 percentage points (Model 3 ) to 0.34 percentage points (Model 4 ) with the average of the growth was 3.73 per cent as presented in Table 2 .

Moreover, this study breaks down the nrrev into mining revenue (miningrev) and oil and gas revenue (oilgasrev) to further examine the variables potentially leading to the curse. When the model employed oilgasrev, there was strong evidence that the curse may exist in Indonesia. As shown by Model 7 and Model 8 in Table 3, both paired with credit and deposit indicators, oilgasrev was associated negatively with economic growth. One percentage point of oilgasrev increase would drive to lower economic growth by 0.33 percentage points (Model 7) to 0.34 percentage points (Model 8). Those were in line with within-country natural resource curse studies. Douglas and Walker (2016) and Papyrakis and Gerlagh (2007) found a negative relationship between natural resources and economic growth in the USA. 
Ridena, Nurarifin, Hermawan, \& Komarulzaman

Testing the Existence of Natural Resource Curse in Indonesia: ...

Table 3 Relationships between natural resource dependence, financial development, and economic growth

\begin{tabular}{|c|c|c|c|c|c|c|c|c|}
\hline & $\begin{array}{c}\text { Model } \\
1 \\
\end{array}$ & $\begin{array}{c}\text { Model } \\
2 \\
\end{array}$ & $\begin{array}{c}\text { Model } \\
3 \\
\end{array}$ & $\begin{array}{c}\text { Model } \\
4 \\
\end{array}$ & $\begin{array}{c}\text { Model } \\
5 \\
\end{array}$ & $\begin{array}{c}\text { Model } \\
6 \\
\end{array}$ & $\begin{array}{c}\text { Model } \\
7 \\
\end{array}$ & $\begin{array}{c}\text { Model } \\
8 \\
\end{array}$ \\
\hline Initial income & $\begin{array}{c}- \\
0.0827 \\
* * * \\
(0.05)\end{array}$ & $\begin{array}{c}- \\
0.0875 \\
* * * \\
(0.10)\end{array}$ & $\begin{array}{c}- \\
0.0365 \\
* * * \\
(0.03)\end{array}$ & $\begin{array}{c}- \\
0.0302 \\
* * * \\
(0.01)\end{array}$ & $\begin{array}{c}- \\
0.0228 \\
* * * \\
(0.04)\end{array}$ & $\begin{array}{c}- \\
0.0367 \\
* * * \\
(0.01)\end{array}$ & $\begin{array}{c}- \\
0.0447 \\
* * * \\
(0.02)\end{array}$ & $\begin{array}{c}- \\
0.0338 \\
* * * \\
(0.01)\end{array}$ \\
\hline $\begin{array}{l}\text { Mining dependence } \\
\text { GRDP (mindep) }\end{array}$ & $\begin{array}{l}0.0043 \\
(0.01)\end{array}$ & $\begin{array}{l}0.0026 \\
(0.01)\end{array}$ & & & & & & \\
\hline $\begin{array}{l}\text { Natural resource } \\
\text { revenue (nrrev) }\end{array}$ & & & $\begin{array}{c}- \\
0.0028 \\
* * \\
(0.00)\end{array}$ & $\begin{array}{c}- \\
0.0034 \\
* * \\
(0.00)\end{array}$ & & & & \\
\hline $\begin{array}{l}\text { Mining revenue } \\
\text { (minrev) }\end{array}$ & & & & & $\begin{array}{c}- \\
0.0063 \\
(0.00)\end{array}$ & $\begin{array}{c}- \\
0.0033 \\
* \\
(0.00)\end{array}$ & & \\
\hline $\begin{array}{l}\text { Oilgas revenue } \\
\text { (oilgasrev) }\end{array}$ & & & & & & & $\begin{array}{c}- \\
0.0033 \\
* * \\
(0.00)\end{array}$ & $\begin{array}{c}- \\
0.0034 \\
* \\
(0.00)\end{array}$ \\
\hline Credit & $\begin{array}{l}0.0018 \\
(0.00)\end{array}$ & & $\begin{array}{l}-0.0010 \\
(0.00)\end{array}$ & & $\begin{array}{l}0.0007 \\
(0.00)\end{array}$ & & $\begin{array}{c}- \\
0.0007 \\
(0.00)\end{array}$ & \\
\hline Deposit money bank & & $\begin{array}{r}0.0018 \\
(0.00)\end{array}$ & & $\begin{array}{r}-0.0001 \\
(0.00)\end{array}$ & & $\begin{array}{r}0.0006 \\
(0.00)\end{array}$ & & $\begin{array}{c}- \\
0.0000 \\
(0.00)\end{array}$ \\
\hline Mindep*credit & $\begin{array}{c}-0.0002 \\
(0.00)\end{array}$ & & & & $\begin{array}{l}0.0002 \\
(0.00)\end{array}$ & & & \\
\hline Mindep*deposit & & $\begin{array}{c}-0.0001 \\
(0.00)\end{array}$ & & & & $\begin{array}{l}0.0001 \\
(0.00)\end{array}$ & & \\
\hline Nrrev*credit & & & $\begin{array}{c}0.0001 \\
*\end{array}$ & & & & 0.0001 & \\
\hline & & & $(0.00)$ & & & & $(0.00)$ & \\
\hline Nrrev*deposit & & & & $\begin{array}{c}0.0001 \\
* * *\end{array}$ & & & & \\
\hline & & & & $(0.00)$ & & & & \\
\hline Minrev*credit & & & & & $\begin{array}{c}0.0002 \\
(0.00)\end{array}$ & & & \\
\hline Minrev*deposit & & & & & & $\begin{array}{l}0.0001 \\
(0.00)\end{array}$ & & \\
\hline Oilgasrev*credit & & & & & & & $\begin{array}{l}0.0001 \\
(0.00)\end{array}$ & \\
\hline Oilgasrev*deposit & & & & & & & & $\begin{array}{c}0.0001 \\
* * * \\
(0.00)\end{array}$ \\
\hline Control variables & YES & YES & YES & YES & YES & YES & YES & YES \\
\hline Time Effects & YES & YES & YES & YES & YES & YES & YES & YES \\
\hline$A R(1) p$ & 0.1147 & 0.1199 & $\begin{array}{c}0.0786 \\
*\end{array}$ & $\begin{array}{c}0,0731 \\
*\end{array}$ & $\begin{array}{c}0.0461 \\
*\end{array}$ & $\begin{array}{c}0.0815 \\
*\end{array}$ & $\begin{array}{c}0.0831 \\
*\end{array}$ & $\begin{array}{c}0.0860 \\
*\end{array}$ \\
\hline$A R(2) p$ & 0.1280 & 0.5116 & 0.4275 & 0.4246 & $\begin{array}{c}0.0542 \\
*\end{array}$ & $\begin{array}{c}0.0332 \\
* *\end{array}$ & 0.2552 & 0.2867 \\
\hline $\begin{array}{l}\text { Hansen/Difference-in- } \\
\text { Hansen Test } \mathrm{p}\end{array}$ & 0.8886 & 0.7234 & 0.5660 & 0.5411 & 0.6745 & 0.8558 & 0.6482 & 0.5992 \\
\hline Instrument & 22 & 22 & 22 & 22 & 22 & 22 & 22 & 22 \\
\hline Province & 33 & 33 & 33 & 33 & 33 & 33 & 33 & 33 \\
\hline
\end{tabular}

Notes: Standard errors in parentheses. The symbol $*, * *$, and ${ }^{* * *}$ show that the variables are significant at $10 \%, 5 \%$, and $1 \%$, respectively. 
Rongwei and Xiaoying (2020) had also detected a negative association between resource endowment and economic growth in China. In Indonesia, Komarulzaman and Alisjahbana (2006) also claimed that the nexus between those two variables was negative.

Badeeb et al. (2017) stated that there are reasons behind the negative association between natural resources and economic growth. They are classified into economic and political channels. From an economic perspective, the curse may relate to 'Dutch disease', commodity price volatility, economic policy failures, and the neglect of education. On the other hand, from the political point of view, the channels are traced to rent-seeking and weak institutions, and corruption.

The explanations of why the curse may exist in Indonesia are potentially consistent with statements of Badeeb et al. (2017). Like other countries in the world, Indonesia has also encountered a boom and recession in its economy. Indonesia has often been classified as a developing country that is successfully escaped from the resource curse trap during the 1970 s to 2000s, the conditions in which natural-resource-based economic growth could foster industrialization processes leading to economic welfares and poverty alleviation. However, after the 2000s, the condition in which labour-intensive agricultural products play a critical role in economic activities, Indonesia's economy experienced all the symptoms of the modern Dutch disease, persisting to grow while export-oriented and more skilled services sectors remain stable (Edwards, 2016). Most of Indonesia's international health and education comparisons have been relatively poor; hence, the progress of poverty alleviation has slowed, while inequality gradually increases.

In addition to the Dutch disease, Indonesia probably had high price volatility and policy mismanagement. Badeeb et al. (2017) argued that price volatility could reduce economic growth since market instability may increase uncertainty, leading to difficulties to measure natural resource revenues so that government faces challenges to formulate economic development planning. Furthermore, natural resource revenues often make policymakers overconfident. For instance, natural-resource-based fiscal often drove the government to be ignorant to set policies relating to urbanization, human capital development, and infrastructure that was prominent for long-term economic growth (Badeeb et al., 2017).

In the meantime, politically, rent-seeking, corruption, and weak institution quality remain as challenges for Indonesians. According to Badeeb et al. (2017), in many countries, natural resource abundance enhanced the power of elites since they can take a large portion of natural resource revenues and to share the revenues with particular groups in their circle rather than to boost infrastructure or sustainable economic development. Furthermore, they argued that institution quality plays a crucial role in determining whether natural resources could become a blessing or a curse. Natural resources could not only become a main driver of conflicts but also corruption and pressure on institution quality. In Indonesia, corruption has become a serious issue. According to the corruption perception index of Transparency International, Indonesia ranked 85th of 180 countries. This becomes a potential reason why the curse exists or persists in Indonesia. 


\section{The Role of Financial Development in Mitigating the Curse}

In addition, to examine the relationship between natural resource dependence and economic growth, Table 3 also presents the role of financial development in mediating the linkages between natural resources and economic output. Individually, the effect of financial development on per capita output was not statistically significant in all specifications. Meanwhile, the interaction terms between financial development and natural resource dependence were positive and significant, both using credit and deposit money bank as a proxy for financial development. This indicates that financial development may become a channel for mitigating the natural resource curse in Indonesia. According to Model 3 and Model 4 in Table 3, the interaction terms between nrrev and private credit and deposit money bank were significant and positive. Specifically, it is the interaction between oilgasrev and deposit money bank that was significant and positive (Model 8), but not statistically significant between oilgasrev and private credit (Model 7).

To calculate the threshold in which financial development mitigates the curse, it needs to take a partial derivative of the standard model used in this study, as written in equation (1c). Following Rongwei and Xiaoying (2020), the formula is as follows;

$\frac{\partial y}{\partial N R} \geq \beta_{1}+\beta_{3} F D$

Table 4 Relationships between natural resource dependence, financial development, and economic growth

\begin{tabular}{lccc} 
& $\begin{array}{c}\text { Coefficient } \\
\beta_{1}\end{array}$ & $\begin{array}{c}\text { Coefficient } \\
\beta_{3}\end{array}$ & $\begin{array}{c}\text { The Threshold of } \\
\text { Financial Development }\end{array}$ \\
\hline Nrrev*credit & -0.0028 & 0.0001 & 28 \\
Nrrev*deposit & -0.0034 & 0.0001 & 34 \\
Oilgasrev*deposit & -0.0034 & 0.0001 & 34 \\
\hline
\end{tabular}

Table 3 shows that only Model 3 and Model 4 confirm the existence of the natural resource curse in Indonesia. In Model 3 and Model 4, the interaction terms between natural resources and financial development were significant and positive. Table 4 presents the thresholds in which financial development could mitigate and minimize the curse. The interaction coefficient between nrrev and private credit was 0.0001 , indicating private credit could reduce the curse if its level is accounted for at least 28 per cent. Moreover, the interaction coefficient between nrrev and deposit money bank was also 0.0001 , indicating that deposit money bank could mitigate the natural resource curse when its level is approximately at least 34 per cent. Finally, the interaction coefficient between oilgasrev and deposit money bank was accounted for 0.001 , reflecting deposit money bank could mitigate the curse after reaching the threshold at 34 per cent.

Those results indicate that financial development is potential to be a mechanism that minimizes the natural resource curse in a country. The study finds that private credit and deposit money banks should be at least 28 per cent and 34 per cent, respectively. According to descriptive statistics in Table 2, the average of private credit and deposit 
money banks was 24.92 per cent and 25.92 per cent, respectively. It helps the policymakers to formulate economic development policies by considering natural resource quality. Enhancing financial development could be a crucial way to avoid and anticipate the existence of the curse. These results are consistent with the studies conducted by Moradbeigi and Law (2017), and Rongwei and Xiaoying (2020).

Moradbeigi and Law (2017) found that financial development could reduce the negative effect of natural resource endowment, especially oil, on economic growth when the level of financial development of a country was between 19 per cent and 34 per cent. The threshold in developing countries tends to be higher than in developed countries since the level of financial development remains low in developing countries. Additionally, Rongwei and Xiaoying (2020) argued that the level of financial development should be at least 17 per cent to mitigate the curse in China.

Rongwei and Xiaoying (2020) stated that when a country has a low level of financial development, the investment tends to flow to a virtual economy so that the real economy cannot develop. Following the Federal Reserve definition, they define the real economy term as industries other than the financial sector and real estate, while the virtual economy is on the other way around. In comparison to the virtual economy, the real economy is believed to have a relatively thin profit, low and slow rate of return thereby potentially crowding out other entities. As Rongwei and Xiaoying (2020) argued, this leads to create the virtual economy bubble and endangered economic development. However, when the level of financial development has reached a certain threshold, the investment will also flow to other labour-intensive real sectors and lead to higher economic growth.

Financial development could reduce the curse in two ways. First, when natural resource revenue falls due to price volatility, the financial system could help to finance the shortfall so that it can increase productivity and allocate resources optimally. Second, when natural resource revenue increases, the revenue could help the financial system to be more effective and stronger so that it could boost other sectors, which in turn could foster growth.

\section{Conclusion}

The positive impact of natural resource abundance on economic development has become debatable since firstly constructed a hypothesis of the natural resource curse, revealing the possibility of the negative relationship between natural resources and economic growth. Hence, this seeks to study examine the existence of a natural resource curse in Indonesia and scrutinize the role of financial development in mitigating the curse.

The results have provided evidence of the possibility of the natural resource curse in Indonesia. This study found a negative association between natural resource dependence and economic output growth. One percentage point increase of natural resource revenue would lower the economic growth by 0.28 to 0.34 percentage points. Mining revenue and oil and gas revenue revealed evidence of the existence of the curse in Indonesia. However, 
the latter provided stronger empirical evidence than the first one. The study also finds another crucial finding showing an alternative channel for mitigating the natural resource curse through financial development. Results show that enhancing financial development could potentially mitigate and reduce the negative effect of natural resource dependence on economic growth. The level of financial development has to be at least 28 to 34 per cent so that it gives the desired impact in reducing the natural resource curse.

The findings recommend the government to pay more serious attention to fight the natural resource curse that occurred in the country through effective mechanisms; one of which is through financial development. Enhancing financial development to a certain threshold could mitigate the natural resource curse in the country. In the meantime, policymakers should also guarantee that other reasons causing the natural resource curse can be solved, such as by anticipating modern "Dutch disease", reducing price volatility, eradicating rent-seeking practices, and strengthening the quality of the institution. Finally, the revenues obtained from natural resources with the support of capable financial sectors are believed to boost economic output growth, which in turn increase the living standard of societies.

\section{Acknowledgments}

We would like to acknowledge the valuable supports of BPS-Statistics Indonesia, Otoritas Jasa Keuangan (OJK), and Direktorat Jenderal Perimbangan Keuangan (DJPK) Ministry of Finance of the Republic of Indonesia for providing data used in this study.

\section{References}

Andersen, M. S. (2006). An introductory note on the environmental economics of the circular economy. Sustainability Science, 2(1), 133-140. https://doi.org/10.1007/s11625$\underline{006-0013-6}$

Arellano, M., \& Bond, S. (1991). Some tests of specification for panel data: Monte Carlo evidence and an application to employment equations. The Review of Economic Studies, 58(2), 277-297. https://doi.org/10.2307/2297968

Arellano, M., \& Bover, O. (1995). Another look at the instrumental variable estimation of error-components models. Journal of Econometrics, 68(1), 29-51.

https://doi.org/10.1016/0304-4076(94)01642-d

Atkinson, G., \& Hamilton, K. (2003). Savings, growth and the resource curse hypothesis. World Development, 31(11), 1793-1807. https://doi.org/10.1016/i.worlddev.2003.05.001

Auty, R. M. (1994). Industrial policy reform in six large newly industrializing countries: The resource curse thesis. World Development, 22(1), 11-26. https://doi.org/10.1016/0305750x(94)90165-1

Badeeb, R. A., Lean, H. H., \& Clark, J. (2017). The evolution of the natural resource curse thesis: A critical literature survey. Resources Policy, 51, 123-134. https://doi.org/10.1016/i.resourpol.2016.10.015

Barro, R. J. (1996). Determinants of economic growth: A cross-country empirical study. National Bureau of Economic Research. Retrieved from https://www.nber.org/system/files/working_papers/w5698/w5698.pdf 
Beck, T. (2011). Finance and oil: is there a resource curse in financial development? SSRN Electronic Journal. European Banking Center Discussion Paper No. 2011-004. https://doi.org/10.2139/ssrn.1769803

Ben-Salha, O., Dachraoui, H., \& Sebri, M. (2018). Natural resource rents and economic growth in the top resource-abundant countries: A PMG estimation. Resources Policy, 101229. https://doi.org/10.1016/i.resourpol.2018.07.005

Blundell, R., \& Bond, S. (1998). Initial conditions and moment restrictions in dynamic panel data models. Journal of Econometrics, 87(1), 115-143. https://doi.org/10.1016/s0304$\underline{4076(98) 00009-8}$

Cavalcanti, T. V. de V., Mohaddes, K., \& Raissi, M. (2011). Growth, development and natural resources: new evidence using a heterogeneous panel analysis. The Quarterly Review of Economics and Finance, 51(4), 305-318. https://doi.org/10.1016/i.qref.2011.07.007

Das, A., Chowdhury, M., \& Seaborn, S. (2016). ICT diffusion, financial development and economic growth: new evidence from low and lower middle-income countries. Journal of the Knowledge Economy, 9(3), 928-947. https://doi.org/10.1007/s13132-016-0383-7

Douglas, S., \& Walker, A. (2016). Coal mining and the resource curse in the Eastern United States. Journal of Regional Science, 57(4), 568-590. https://doi.org/10.1111/jors.12310

Edwards, R. B. (2016). Natural resource sectors and human development: International and Indonesian evidence. Thesis. Australian National University

Erdoğan, S., Yıldırım, D. Ç., \& Gedikli, A. (2020). Natural resource abundance, financial development and economic growth: An investigation on Next-11 countries. Resources Policy, 65, 101559. https://doi.org/10.1016/i.resourpol.2019.101559

Gelb, A.H. (1988). Oil windfalls: Blessing or curse? Oxford University Press, Oxford.

Gylfason, T. (2004). Natural resource and economic growth: from dependence to diversification. Retrieved from https://ethz.ch/content/dam/ethz/specialinterest $/ \mathrm{mtec} /$ cer-eth $/$ resource-econ-dam/documents/research/ws-and-conf $/ \mathrm{sgvs}$ 2005/029.pdf

Gylfason, T., \& Zoega, G. (2006). Natural resources and economic growth: the role of investment. The World Economy, 29(8), 1091-1115. https://doi.org/10.1111/j.14679701.2006.00807.x

Havranek, T., Horvath, R., \& Zeynalov, A. (2016). Natural resources and economic growth: a meta-analysis. World Development, 88, 134-151. https://doi.org/10.1016/j.worlddev.2016.07.016

Hilmawan, R., \& Clark, J. (2019). An investigation of the resource curse in Indonesia. Resources Policy, 64, 101483. https://doi.org/10.1016/i.resourpol.2019.101483

Komarulzaman, A., \& Alisjahbana, A. S. (2006). Testing the natural resource curse hypothesis in Indonesia: Evidence at the regional level. Working Papers in Economics and Development Studies (WoPEDS). Retrieved from https://ideas.repec.org/p/unp/wpaper/200602.html

Marques, A. C., \& Pires, P. S. (2019). Is there a resource curse phenomenon for natural gas? Evidence from countries with abundant natural gas. Resources Policy, 63, 101466. https://doi.org/10.1016/j.resourpol.2019.101466

Michaels, G. (2010). The long term consequences of resource - based specialisation. The Economic Journal, 121(551), 31-57. https://doi.org/10.1111/i.1468-0297.2010.02402.x

Moradbeigi, M., \& Law, S. H. (2017). The role of financial development in the oil-growth nexus. Resources Policy, 53, 164-172. https://doi.org/10.1016/i.resourpol.2017.06.016

Papyrakis, E., \& Gerlagh, R. (2007). Resource abundance and economic growth in the United States. European Economic Review, 51(4), 1011-1039.

https://doi.org/10.1016/i.euroecorev.2006.04.001 
Ridena, Nurarifin, Hermawan, \& Komarulzaman

Testing the Existence of Natural Resource Curse in Indonesia: ...

Rahma, H., Fauzi, A., Juanda, B., \& Widjojanto, B. (2021). Fenomena natural resource curse dalam pembangunan wilayah di Indonesia. Jurnal Ekonomi dan Pembangunan Indonesia, 21(2), 148-163. https://doi.org/10.21002/jepi.v21i2.1358

Rongwei, X., \& Xiaoying, Z. (2020). Is financial development hampering or improving the resource curse? New evidence from China. Resources Policy, 67, 101676. https://doi.org/10.1016/j.resourpol.2020.101676

Roodman, D. (2009). How to do Xtabond2: an introduction to difference and system GMM in Stata. The Stata Journal: Promoting Communications on Statistics and Stata, 9(1), 86-136. https://doi.org/10.1177/1536867x0900900106

Rosser, A. (2007). Escaping the resource curse: The case of Indonesia. Journal of Contemporary Asia, 37(1), 38-58. https://doi.org/10.1080/00472330601104557

Sachs, J.D., \& Warner, A.M. (1995). Natural resource abundance and economic growth. National Bureau of Economic Research, Working Paper 5398. Retrieved from https://www.nber.org/system/files/working_papers/w5398/w5398.pdf

Transparency International. (2020). Corruption perceptions index. Transparency International. Retrieved from https://www.transparency.org/en/cpi/2019/index/idn 